\title{
Population, Poverty and Economic Development Nexus: Empirical Study of Some Selected Developing Countries
}

\author{
Muhammad Sibt e Ali ${ }^{1}$, Syed Muhammad Faraz Raza ${ }^{2}$, Naeem ul Din ${ }^{3}$, Syed Zain Ul \\ Abidin $^{4}$ \\ ${ }^{1,3}$ M. Phil Scholar, School of Economics, Bahauddin Zakariya University Multan, Pakistan \\ ${ }^{2,4}$ M. Phil Scholar, National University of Modern Languages Islamabad, Pakistan \\ Email: ali4bzu@gmail.com
}

\begin{abstract}
The major objective of this research is to examine the connection among poverty, population growth and its impact on economic development of different developing countries. This research comprised of panel data for period of 2002-2015. The data has been taken World Bank Indicator (WDI) for twenty six developing countries. To find out the results we use panel data. For the analysis of data we have applied Hausman and Fixed Effect Model in this study. Findings of the study indicate that the consumption of government, export, gross capital formation and industrial value added have positive impact on growth of developing economies. The results show that the variation in these variables has positive effect on dependent variables. On the other hand, economic growth increases due to positive changes in this variable. It is seen in this study that population and poverty has negative impact on GDP per capita in selected developing countries.
\end{abstract}

Keywords: Economic Growth; Economic Development; Poverty; Human Capital

\section{Introduction}

The population of any country plays a vital part in economic development. Rapid increase in population directly affects the economic growth in under developed countries of the world. On the other hand, resources are limited and rapid increase in population has exerted pressure on limited resources. Rapid increase in population, reduce investment in both the public and private sector and also decrease capital assets of the developing countries.

Poverty is one of the serious issues in under developed countries of the world. People are not in a position to fulfill the basic needs of life. They are not in a position to enjoy the modern facilities of life, as the people being enjoying in advance countries of the world. They have no access to safe drinking water; less food is available, lack of nutrition, low living 
standard facilities and low standard of dressing. They are not in a position to avail facilities of modern technology.

Poverty is a global issue and directly affects the human beings which are living in under developed countries of the world. Poverty increases due to many reasons such as low level of education, unskilled labor, increase in fertility rate, gender discrimination and increase in unemployment. Poverty directly affects the pace of economic growth of developing countries in different parts of the world. Role of human capital is important in the development of any country.

Resources are limited and increase in population badly affects the pace of economic growth in under developing countries. Increase in population, increases pressure on existing resources of the country. Less resource is available to the increasing population.

Economic development is the last hope to increase the living standards in under developing countries. On the other hand, developing countries spend less than one percent of gross domestic product to reduce poverty in the country. More steps are required to reduce poverty from the world.

The objective of this study is to determine the role of population, poverty and their impact on selected developing countries. Estimate the relationship among poverty, population and economic development in developing countries. And to explore the ways to reduce poverty and population controls in developing countries and to increase economic development in developing countries. While this present research has significance because of its unique combination of selected countries. The selected countries have the combination of low, lower middle and upper income countries. There is need to identify the poverty and population nexus with economic development of developed and developing countries. While the indicators of population and poverty is significant to measure the economic development in the presence of poverty and population issues.

In this study section one tells us about the introduction of the study. Section two tells us about the previous studies. Data and methodology is explained in section three. Results and their imperial relation are discussed in section four. In the last section conclusion and policy recommendation is discussed.

\section{Literature Review}

Numerous researches have been conducted to examine the link among poverty, population and economic development in different countries of the world. The results of the previous studies show that economic growth is affected due to increase in population in under 
developed countries of the world. Resources are limited to fulfill the needs of increasing population. Different measure must be taken to control the increasing population.

Mehanna (2004) analyzed the effect of poverty on economic development in developing countries. In this article, the link between unusual set of poverty and economic growth is measured. To find out the results of the study we use Co-integration and granger test. The results of the study show long run relationship between two or more variables. Result showed the feedback apparatus between poverty, crime and economic development. On the other hand income inequalities have no main effect on other variables.

Kraay and Raddatz (2007) examine the role of aid, poverty traps and growth. The main focus of this research is to consider possible hypothetical mechanisms producing poverty traps and partial enormously representation of development. The main objective of this research is to use micro and macro data that other processes were empirically main as well explained for underdevelopment. The result of the study show that more aid effect the process of growth.

Nissim (2007) analyzed the effects of income distribution on economic development. This research use time serious data in the study. Lapping generation model has been used to find out the result. The belongings of the economic development on work force and allocation of earnings. The results of the research show that when capital stock increases, workers get better jobs so in this situation, income distribution becomes stable.

Spencer and Myer (2007) examine the importance of population and their effect on economy in Pennsylvania and Cambria countries. This research also examines the short and long run effects of flood in 1977. The result of the research shows that unemployment rate increases and on the other hand population also decreases. Due to the natural calamity, population decreases and unemployment also increases in the country. This research shows the effect of natural calamities on Cambia countries.

Saab (2007) said that social commission plays a significant role in economic growth in Asian countries. The result of the research tells us that direct investment and capital formation is important for the development and growth of the countries. Economic development of the country is directly linked with direct investment. We must encourage the manufacturing sector to promote the industrial sector which is helpful in the development of the countries.

Akoum (2008) said that poverty should be decreased. The high rate of growth is reduced the poverty level of the economy and promoted the globalization. The countries that 
have high growth rate, their poverty rate are less. The research is conducted to measure the impact of high rate of growth on poverty. The results are contrary to theory. The high growth countries are failed to reduce poverty.

Goh et al. (2009) studied the effect of education on growth, income and inequality of eight provinces of china. Both the rural and urban areas are included to measure the affect in poverty and inequality by education. The analysis proved that the inequality in income of rural and urban areas is reduced by education. While the income level is increased and poverty is reduced. The rural areas showed much increase in income and reduction in poverty than urban areas. While the inequality is reduced in between the income of urban and rural areas.

Kalirijan (2009) measured the effect of improved infrastructure, growth of agriculture sector and foreign capital on poverty reduction. The empirical findings proved the reduction in poverty by increased foreign capital, infrastructure and high growth of agriculture sector.

Qureshi (2009) investigated the influence of public expenditures on economic and human development. While the causation in between population and economic development is found in this research. The results not showed much increase in human development by public expenditures. While the bi-directional causality is found between economic development and population.

Ferreira et al. (2010)examined the association among sustained poverty and economic development. The findings proved the increase in development level of the economy. The results proved that the sustained poverty encourages the economic development. While the reduction in poverty is also the cause of increased in economic development. In another research, the findings verified the reduction in poverty by increased economic development. (Montalvo and Ravallion, 2010)

Dao (2012) inspected the association of population with growth in emerging nations. The empirical analysis proved the negative association between population and growth of developing countries. Economic growth of developing countries is reduced by increased population.

Azam and Emirullah (2014) explored that the influence of governance on poverty and growth in nine countries of Asia and Pacific. The study used the fixed and random effect techniques. The results showed the reduction in economic growth due to increase in corruption and inflation. While poverty is increased in these countries. In another research, 
the findings exposed the increase in poverty due lack of human and physical capital in developing countries. (Dao, 2014)

Uddin (2014) investigate the relationship between financial development, economic growth and poverty reduction in Bangladesh. The data from year 1975to 2011 has been used in this study. ARDL model is used to find out the result of the study. The result shows that there is a long run relationship exists between economic growth development and poverty reduction in Bangladesh. Poverty is reduced and its effect is non-linear.

Oliver (2015) studied the effect of population on growth of Japan's economy. The researcher used the different groups of population like schooling, old age, female and male labor force. The results proved the increase in economic growth when the schooling and female participation is increased in population. Overall effect of population showed the negative influence of on growth level of economy of Japan.. While, the participation of female in labor force has enhanced the GDP.

Fosu (2016) studied the association among, income, poverty and inequality in developing nations. The findings proved that the average income has reduced the poverty. While inequality is still the problem for developing countries. Mostly developing nations are failed to distribute income equally.

Boukhatem (2016) said that financial development is not possible without reduction in poverty. The data from year 1986 to 2012 has been used in this study. The data is obtained from 67 middle and low income countries. The result of the study shows that low investment in public sector is the main cause of poverty in low and middle income countries.

Adonsou \& sylwester (2016) said that there is a close link between poverty, economic development in developing countries. The panel data from 71 countries from year 2020 to 2011 has been used in this study. Fixed effect and two-stage model is used to find out the results. The result of the study shows that MFI's does not impact on poverty reduction. The results also show that banks have the ability to reduce poverty.

Seven \& coskun (2016) said that without the reduction in poverty financial development is not possible. The panel data from year 1987 to 2011 has been used in this study. The result of the study shows that in finance-poverty link, stock market and banks does not play a good role in poverty reduction and development of financial sectors and economic development.

Sasmal (2016) measured the public expenditures on infrastructure and its influence on economic development and poverty. The findings indicated that the public expenditures on 
infrastructure like electricity, irrigation, transportation and roads has constructive effect on economic development. While public expenditures are not much affective for poverty reduction.

The unique combination of poverty and population indicators and selection of countries provide the gap between the present study and the previous study. In this study low, lower middle income countries and upper middle income countries are considered to identify the role of population and poverty in growths of economic development of selected economies.

\section{Data and Methodology}

In this research we use secondary data of twenty six countries. Data has been used from year 2002 to 2015.Data has been mainly collected from World Bank, IMF and International Financial Statistics. The twenty six countries which are as follow: Belarus, Bolivia, Brazil, Czech Republic, Dominican Republic, Ecuador, Honduras, Indonesia, Jamaica, Kazakhstan, Latvia, Lithuania, Moldova, Montenegro, Pakistan, Paraguay, Peru, Poland, Russia, Slovenia, Slovakia, Thailand, Turkey, Ukraine, Venezuela, West Bank and Gaza. This research used the combination of developing and developed nations by their region and income level. The countries are selected from whole world in which some countries have lower income, some have middle and upper income level. Here in this study the selected developed nation are still focusing on their development process and that's why these countries are considered in upper income with lower and middle income economies.

\section{A. Model Specification}

Model specification is very impotent step to find out the relationship of dependent and independent variable. We use different variables to find out the relationship of poverty, population and their effect on economic development of some selected developing countries. According to the theoretical point of view, high population in developing nations has destructive effect of economic development while the poverty has increased. The situation for developed nations is different. Developed nations are not much affected in negative way when their population is increased which has been proved in past studies. While without seeing the geographical conditions, the theory said that, increased level of poverty and population has negative influence on economic development. According to the econometric model, this study is based on Qureshi (2009), Azam and Emirullah (2014) and Adonsou \& sylwester (2016). Adonsou \& sylwester (2016)study is based on the fixed effect model. This 
research is followed almost same techniques and combination of variables which are used in base researches.

Following is the main equation

$$
G D P P C=f(P O P, G C F, P H C, G C, E G S, I V A)
$$

GDP is used as an independent variable in this research

GDPPC $=$ Gross Domestic Product Per Capita

$\begin{array}{lll}\text { PT } & =\text { Total Population } \\ \text { GCF } & & \text { Gross Capital Formation } \\ \text { PHC } & = & \text { Poverty Headcount Ratio } \\ \text { GC } & = & \text { Government Consumption } \\ \text { EGS } & = & \text { Export of Goods and Services } \\ \text { IVA } & = & \text { Industrial Value Added }\end{array}$

Here, the model is presented in the form of econometric equation. The econometric equation have logarithm of all variables.

$$
L G D P P C_{i t}=\alpha_{i t}+\alpha_{1}(L P O P)_{i t}+\alpha_{2}(G C F)_{i t}+\alpha_{3}(P H C)_{i t}+\alpha_{4}(G C)_{i t}+\alpha_{5}(E G S)_{i t}+\alpha_{6}(I V A)_{i t}+\mu_{\mathrm{it}}
$$

\section{B. Concepts of Variables used in the Study}

Different variables are used to find out the influence of poverty and population on development level of economies of emerging nations. The explanation of the variables as fellows;

\section{Gross Domestic Product Per Capita (Dependent variable)}

GDP shows the total output of the country. When GDP per capita increases, it will directly affect the poverty level. When poverty level decreases the pace of economic growth increases in the country. We measure GDP per capita in current U.S dollar in this research. When GDP per capita increases, it increases the living standard of the common people in developing countries.

\section{Population, total}

Population total is very important independent variable. Population total tells us about the total number of people living in the country. Censuses conducted to find out the total number of person living in the country. Population total is very important for the distribution of resources in the country.

\section{Poverty Head Count Ratio}

Poverty Head County ratio is used to find out the total number of person living below the poverty line. Poverty head count ratio is used to find the poverty level in the country. 
Pakistan Journal of Humanities and Social Sciences, 6(4), 2018

Poverty level directly affects the economic growth of the country. When poverty level increase in the country economic growth decreases. The goal of economic growth cannot be achieve without decrease in poverty.

\section{Gross Capital Formation}

Another important variable is gross capital formation. It shows the increase in new capital asset of the country. Economic growth of the country is directly linked with capital assets of the country. When capital assets of the country increase, it directly increases the pace of economic growth of the country.

\section{Government consumption expenditure}

Governments of different countries make different consumption expenditure to fulfill the basic needs of the people. It also includes different expenditure on goods and services made by the government. It has been used as an independent variable in this research. Government consumption directly connected with the economic growth of the country.

\section{Exports of Goods and Service}

Exports of goods and services are considered as important variable in this research. Exports means goods and services send to another country. It is a big source of revenue and helpful to increase the economic growth of the country. When exports of the country increase it increase the foreign reserves of the country. We measure the exports of goods and services in US dollars.

\section{Industrial Value Added}

It has been used as an independent variable in this research. It is projected by total net output occupier industrial units working in the country. It includes both the public and private sector industries working in the country. Industrial value added is directly linked to economic growth of the country. Economic growth of the county is directly linked with the industrial value added increase.

\section{Results and Discussions}

In this section, we present the econometric and statistical data analysis. Descriptive statistics tell us about the main quantitative features of the data use in this study. This gives us the simple summaries about the data. Following table provide the detail of descriptive statistics of the variable of our models.

Table 1: Descriptive Statistics of Variables of Selected Developing Countries

\begin{tabular}{|l|l|l|l|l|l|l|l|}
\hline & $\begin{array}{l}\text { GDP per } \\
\text { capita } \\
(\$)\end{array}$ & $\begin{array}{l}\text { Gross } \\
\text { capital }(\$)\end{array}$ & $\begin{array}{l}\text { Population } \\
\text { total }\end{array}$ & $\begin{array}{l}\text { Poverty } \\
\text { headcount } \\
\text { ratio }\end{array}$ & $\begin{array}{l}\text { Expenditures } \\
(\$)\end{array}$ & Exports (\$) & Value added \\
\hline
\end{tabular}




\begin{tabular}{|l|c|c|c|c|c|c|c|}
\hline Mean & 6809.21 & 51700 & 43385543 & 24.77 & 38800 & 69100 & 70700 \\
\hline Median & 4981.87 & 14600 & 1026057 & 20.15 & 9230 & 27900 & 20200 \\
\hline Maximum & 27501.81 & 538000 & 258000000 & 83.30 & 489000 & 592000 & 638000 \\
\hline Minimum & 458.68 & 188 & 609828 & 1.50 & 319 & 478 & 277 \\
\hline Std. Dev. & 5699.28 & 93800 & 65185959 & 16.44 & 82000 & 99800 & 119000 \\
\hline Skewness & 1.31 & 3.11 & 1.79 & 1.03 & 3.70 & 2.61 & 2.69 \\
\hline Kurtosis & 3.91 & 12.79 & 5.10 & 3.34 & 16.80 & 11.23 & 10.38 \\
\hline
\end{tabular}

Author's Calculation

Table 1 gives us the descriptive analysis of the entire variable used in this research. This table gives us the information about the maximum and minimum values, std. deviation. The mean value of GDP is $6809.21 \$$ and the median value is $4981.87 \$$.It is unstable as it deviate from its average value by 5699.28. Average value of gross capital formation is 51700 million US dollars which is larger than its median value of 14600 million US dollars. Gross capital formation deviates from its mean value by standard deviation value of 93800 so it is also not stable. The population total has the mean value of 43385543 as compared to median value of 1026057. It has been observed that it is also unstable as the values disperse from mean value by the standard deviation value of 65185959 .

The descriptive analysis shows the average value of poverty headcount ratio as 24.77 as compared to median value of 20.15 . The value of standard deviation is 16.44 which show that this is the most stable variable used in this research. Because it is deviated less than other variables from its mean value.

Government consumption has the mean value of 38800million US dollars and median value is 9230 . The deviance from its mean value is 82000 that are obtained by standard deviation. It is observed that the average value of export of goods and services is 69100 greater than its median value of 27900 . It disperses from mean value by99800 million U.S dollar's value of standard deviation. All upper values are measured in millions dollars of US. The average of industrial value added is 70700 million U.S dollars and median value is observed 20200. It is observed that statistically industrial value added is the most unstable among all variables used in the study as its value of standard deviation which is 119000 shows large dispersions from its mean value.

Skewness is the measure of symmetry. Statistically all the variables which have born used in the study are positively skewed. Kurtosis determines the peak level of the variables. So it is seen that statistically all the variables are leptokurtic (highly peaked) except total population which is platykurtic (less peaked).

\section{A. Fixed Effect vs Random Effect (Hausman Test)}


Table 2 gives us the results of Hausman test. The table is showing that the null hypothesis is rejected by the Hausman test which is verified by $\mathrm{P}$ value in this table which is 5 percent. The rejection of null hypothesis preferred the fixed effect model.

Table 2: Hausman Test

\begin{tabular}{|l|l|l|l|}
\hline Summary & Chi-Square. Statistic & Chi-Square.d.f. & Probability \\
\hline Random Cross-section & 21.901 & 6 & 0.001 \\
\hline Author's Calculation & &
\end{tabular}

\section{B. Fixed Effect Model}

The fixed effect model is used to identify the effect of excludes variables by capturing the dummy variables and to constant the cross sections in every time period. That's why the fixed effect model is best fitted model to identify the nexus of population, poverty and economic development by remaining each cross section constant. The results of the model show the impact of dependent variable on independent variable. Significant or insignificant variables can be checked with the help of probability values. Azam and Emirullah (2014) and Adonsou \& sylwester (2016) provide the evidence of poverty and economic development by using fixed effect model. Following are main finding of fixed effect model,

\section{Table 3: Fixed Effect Model}

Dependent variable: GDP per capita

\begin{tabular}{|l|ll|ll|}
\hline Variable & Coefficients & Standard. Error & t-Statistic & Probability. \\
\hline LPT & -1.184 & 0.070 & -16.683 & 0.000 \\
\hline LGCF & 0.112 & 0.021 & 5.338 & 0.000 \\
\hline LPHC & -0.021 & 0.008 & -2.538 & 0.011 \\
\hline LGC & 0.420 & 0.022 & 18.748 & 0.000 \\
\hline LEGS & 0.042 & 0.018 & 2.328 & 0.020 \\
\hline LIVA & 0.405 & 0.038 & 10.581 & 0.000 \\
\hline C & 5.078 & 1.082 & 4.690 & 0.000 \\
\hline R-squared & 0.997 & F-statistic & 3688.472 \\
\hline Adjusted R-squared & 0.996 & Prob(F-statistic) & 0.000 \\
\hline Author's Calculation
\end{tabular}

The result of this table is showing the association among GDP per capital and independent variables. The value of $\mathrm{R}^{2}$ is showing that there is 99 percent dependency of GDP per capita is on independent variables.

The coefficient of LPT is -1.184; there is highly significant effect on GDP per capita but the parameter is negative. The results tell us that due to one percent change in LPT will cause 1.18 percent change in GDP per capita. In under developed countries mostly workers are unskilled and they are not able to utilize their abilities which have negative impact on 
GDP per capita. When population of the county increase it increase pressure on existing resources because resources are limited and needs of the increasing population cannot be fulfilled which reduce GDP per capita. Past study has proved the negative association in between economic growth and population. The increased population has reduced the economic growth of developing countries. (Dao, 2012)Oliver (2015) proved the negative effect of population on growth level of the economy of Japan.

GPF value is 0.112 is showing that there is significant and positive effect of GPF on GDP in terms of per capita. Findings tell us that due to one percent change in GPF will increase 0.112 percent in GDP per capita. Results tell us that there is positive and significant effects of increase in GPF will bring huge change in GDP per capital. Due to increase in capital stock investment in the country increases in the country which increase the labor demand and improve the living standard of the common people.

Coefficient of PHC -0.021. The result shows that there is adverse influence of PHC on per capita GDP. In under developed countries, poverty is the core concern which disturbs the pace of economic development in these countries. Due to untrained workers resources are not fully utilized and income level remains low in these countries which directly affects the development process of the developing countries. Due to this poverty increase in the country and it reduces GDP per capita. It is also proved with past study. Economic growth is decreased when the poverty is increased (Azam and Emirullah, 2014). Adonsou \& sylwester (2016) proved that the poverty is not reduced in concerned nation. Seven \& coskun (2016) also not provide the good relationship between poverty and development.

EGS is significant at 1 percent level. The coefficient of GS is 0.420 . The results tell us that there is significant and positive effect of GS on GDP per capita. This shows that $1 \%$ change in GS will change cause of 0.42 percent in GDP per capita. The parameter is highly positive and significant. Due to low income saving of the people is also low. This is the main cause of low level of investment in developing countries. Government invests in different projects to provide basic facilities and increase the living standard of the common people. Due to government investment, employment opportunity increase in the country which have positive effect on growth which is measured in form of GDP.

The value of EGS is 0.042 . The result shows that there is significant and positive impact of EGS on gross domestic product per capita. Due to $1 \%$ increase in EGS it will bring 0.043 percent increase in GDP per capita. Generally in under developed countries labor intensive technology is use to produce goods and services which are less expensive in 
international market. It is helpful in increasing the exports of the country which have positive impact on economic development in developing countries.

There is significant and positive effect of IVA on GDP per capita. Co-efficient of IVA is 0.405 . The results tell us that due to $1 \%$ change in IVA will bring 0.405 percent change in GDP per capita. When industrial output increase in the country, employment opportunity increase in the country and on the other hand country is in a position to increase exports and earn foreign exchange. Due to this balance of trade is achieved.

\section{Causality Test as Pair wise Dumitrescu Hurlin}

The main objective of this Pair wise Dumitrescu Hurlin Panel causality is to find out the casual relationship between variables. Two type of causality bi-directional and unidirectional is found among the variable. The causality is checking the ability of variable to affect each other. The probability value tells us that the variable is significant or not. This test is apply to check the direction of causality exist between the variable. Mehanna (2004) and Qureshi (2009) proved the nexus with the help of causality test. Following are the main findings of the test.

\section{Table 4: Pair wise Dumitrescu Hurlin Causality Test}

\begin{tabular}{|l|l|l|l|}
\hline Null Hypothesis: & W-Stat. & Zbar-Stat. & Prob. \\
\hline LPT does not homogeneously cause LGDPCAP & 4.22 & 1.62 & 0.14 \\
\hline LGDPCAP does not homogeneously cause LPT & 13.01 & 12.11 & 0.00 \\
\hline LGCF does not homogeneously cause LGDPCAP & 2.59 & -0.19 & 0.79 \\
\hline LGDPCAP does not homogeneously cause LGCF & 2.76 & -0.12 & 0.89 \\
\hline LPHC does not homogeneously cause LGDPCAP & 3.21 & 0.40 & 0.80 \\
\hline LGDPCAP does not homogeneously cause LPHC & 6.52 & 4.34 & 0.00 \\
\hline LGC does not homogeneously cause LGDPCAP & 2.81 & -0.21 & 0.91 \\
\hline LG DPCAP does not homogeneously cause LGC & 3.47 & 0.73 & 0.61 \\
\hline LEGS does not homogeneously cause LGDPCAP & 2.14 & -0.90 & 0.41 \\
\hline LGDPCAP does not homogeneously cause LEGS & 2.71 & -0.23 & 0.79 \\
\hline LIVA does not homogeneously cause LGDPCAP & 2.92 & 0.09 & 0.89 \\
\hline LGDPCAP does not homogeneously cause LIVA & 3.69 & 1.04 & 0.31 \\
\hline LGCF does not homogeneously cause LPT & 18.75 & 18.60 & 0.00 \\
\hline LPT does not homogeneously cause LGCF & 5.87 & 3.59 & 0.00 \\
\hline LPHC does not homogeneously cause LPT & 17.78 & 17.50 & 0.00 \\
\hline LPT does not homogeneously cause LPHC & 9.01 & 7.21 & 0.00 \\
\hline LGC does not homogeneously cause LPT & 20.02 & 20.12 & 0.00 \\
\hline LPT does not homogeneously cause LGC & 3.61 & 0.89 & 0.40 \\
\hline LEGS does not homogeneously cause LPT & 6.89 & 4.78 & 0.00 \\
\hline
\end{tabular}




\begin{tabular}{|l|l|l|l|}
\hline LPT does not homogeneously cause LEGS & 2.54 & -0.32 & 0.75 \\
\hline LIVA does not homogeneously cause LPT & 11.84 & 10.57 & 0.00 \\
\hline LPT does not homogeneously cause LIVA & 4.75 & 2.26 & 0.02 \\
\hline LPHC does not homogeneously cause LGCF & 2.83 & 0.03 & 0.98 \\
\hline LGCF does not homogeneously cause LPHC & 5.37 & 3.03 & 0.00 \\
\hline LGC does not homogeneously cause LGCF & 3.35 & 0.63 & 0.53 \\
\hline LGCF does not homogeneously cause LGC & 5.02 & 2.58 & 0.01 \\
\hline LEGS does not homogeneously cause LGCF & 2.96 & 0.16 & 0.87 \\
\hline LGCF does not homogeneously cause LEGS & 2.19 & -0.73 & 0.46 \\
\hline LIVA does not homogeneously cause LGCF & 2.79 & -0.03 & 0.98 \\
\hline LGCF does not homogeneously cause LIVA & 2.07 & -0.87 & 0.38 \\
\hline LGC does not homogeneously cause LPHC & 7.51 & 5.50 & 0.00 \\
\hline LPHC does not homogeneously cause LGC & 3.21 & 0.46 & 0.64 \\
\hline LEGS does not homogeneously cause LPHC & 5.70 & 3.38 & 0.00 \\
\hline LPHC does not homogeneously cause LEGS & 2.45 & -0.43 & 0.67 \\
\hline LIVA does not homogeneously cause LPHC & 7.59 & 5.59 & 0.00 \\
\hline LPHC does not homogeneously cause LIVA & 3.07 & 0.30 & 0.76 \\
\hline LEGS does not homogeneously cause LGC & 1.82 & -1.16 & 0.25 \\
\hline LGC does not homogeneously cause LEGS & 2.65 & -0.19 & 0.85 \\
\hline LIVA does not homogeneously cause LGC & 4.94 & 2.48 & 0.01 \\
\hline LGC does not homogeneously cause LIVA & 4.32 & 1.76 & 0.08 \\
\hline LIVA does not homogeneously cause LEGS & 2.85 & 0.03 & 0.97 \\
\hline LEGS does not homogeneously cause LIVA & 2.24 & -0.67 & 0.50 \\
\hline Author's Calculation & & & \\
\hline
\end{tabular}

The result of the test indicates that log of population total does not homogeneously cause $\log$ of gross domestic product, is accepted. While the situation of null hypothesis in which GDP per capita is not affecting the population is rejected. It is proved that log of population total and log of GDP per capita have one way or uni directional causality. In which just log of GDP per capita causes log of population total. The reason is that, the countries with lower economic growth create problems for their population in the shape of unemployment, poverty and many other problems. The findings not showed any causality in between GDP per capita and formation of gross capita. No change found in GDP per capita which causes by gross capital formation, nor found any change in formation of gross capital which causes by GDP per capita. The hypothesis of log of poverty headcount does not homogeneously affect the log of GDP, is accepted. On the other hand, second situation of null hypothesis is not accepted in which it is stated that log of poverty is not affected by log of GDP. So there is one direction causal relationship among log of poverty head count and log of GDP per capita 
in which only log of GDP per capita causes log of poverty head count. It is cleared when the economy has low growth rate, then their poverty level will rise. The same situation is with these selected countries. Most of selected countries have less growth rate that causes the poverty. In case of log of government consumption and log of GDP per capita, log of government consumption is not considered as the cause of the change in log of GDP per capita and log of GDP per capita also does not considered as the cause of change in the log of government consumption. Similarly, the findings not verified any causality among log of export of goods and services and log of GDP per capita, log of industrial value added and log of GDP per capita.

On the other hand, there is a two way causality relationship among log of GCF and $\log$ of population total as log of gross capital formation does homogeneously cause the log of population total and $\log$ of population total also homogeneously causes log of poverty headcount and log of gross capital formation. Similarly population is also caused by these two variables of poverty and gross capital formation. While in short, the findings verified the two way causality of population with these two variables. It is seen in the above causality test that $\log$ of government consumption homogeneously cause log of population total but log of population total does not homogeneously causes log of government consumption so one directional causality connection is found between these variables in which only log of government consumption homogeneously causes log of population total. A uni-directional Hurlin causality relationship is also found among log of export of goods and services and log of population total in which only log of export of goods and services homogeneously causes $\log$ of population total. It is found that a two-way causality relationship exists among $\log$ industrial value added and $\log$ of population total as both variables homogeneously causes each other.

In the case of log of poverty headcount and log of gross capital formation, the null hypothesis that log of poverty headcount does not homogeneously cause log of gross capital formation is accepted while the null hypothesis that log of gross capital formation does not homogeneously causes log of poverty headcount is rejected. So a one directional causal relationship is found between log of poverty headcount and log of gross capital formation in which only log of gross capital formation homogeneously causes log of poverty headcount. Similarly a uni-directional causality association is also found among log of government consumption and log of gross capital formation in which only log of gross capital formation homogeneously causes log of government consumption. The result shows that log of export 
of goods and services does not homogeneously cause the log of gross capital formation and $\log$ of gross capital formation also does not homogeneously causes the log of export of goods and services so it means that there is no Hurlin causality relationship among log of export of goods and services and log of gross capital formation. Similarly no Hurlin causality relationship is found between log industrial value added and log of gross capital formation as both of these variables does not cause each other.

On the other hand one-directional causality relationship is found among log of government consumption and $\log$ of poverty headcount in which only log of government consumption does homogeneously cause the log of poverty headcount. A one sided causation is measure of $\log$ of goods and services and log of poverty headcount in which good and services does homogeneously cause the log of poverty headcount. The one-directional Hurlin causality relationship is also found among log industrial value added and $\log$ of poverty headcount in which only log industrial value added does homogeneously causes log of poverty head count.

No Hurlin causality relationship is observed between log of goods and services and $\log$ of government consumption. But log of industrial value added and $\log$ of government consumption has two way causality. In detailed, both variables are causing each other's. At the end, the null hypothesis as log industrial value added does not homogeneously cause the $\log$ of exports is accepted and the null hypothesis that log of export of goods and services does not homogeneously causes log industrial value added is also established and rejected the alternative hypothesis of hurlin causality which is showing the causality between these two variables.

\section{Conclusion and Suggestions}

The main objective of this research is to examine the effect of poverty, population and economic development. The data for this research has been taken from World Development Indicator (WDI). Panel data is used for this research for twenty six developing countries for the time period of 2002-2015. The researcher targets their relationship of population, poverty and economic development. Different models such as Hausman, fixed effect technique and causality test has been used to find out the results. The result of the study shows that government consumption, exports of goods and services, and industrial value added, grosses capital formation, and has positive impact on economic growth of developing countries. But on the other hand population and poverty have negative effect. The results obtained the positive change in GDP per capita by all above mentioned variables. The results 
show that there is positive and significant effect of government consumption, total population, gross capital formation and industrial value added on GDP per capita.

On the other hand increase in population puts down GDP per capita. GDP which is measured in the form of per capita has opposite affiliation with population. In under developed countries most of the workers are unskilled and un-trained and they are not able to increase productivity. So this is the main cause of negative impact of population on GDP per capita. Poverty is one of the major issue of developing countries and it effect the economic development process because increasing population require more resources but resources are limited in these countries. Due to unskilled labor, resources are not properly utilized. This is the main cause of low productivity in these countries. When poverty level increases in the country, GDP per capita decreases. So in this situation economic growth is effected due to increase in population. The development process of the developing countries is affected due to increase in population and poverty.

Dumitrescu Hurlin Panel Causality test is used to find out the causality connection between poverty, population and GDP per capita. Result tells us that there is bi-directional causality exist among total population and poverty headcount. On the other only is one directional causality association exists between total population and GDP per capita. So in this situation, we can say that due to increase in population, poverty increase which directly affects the pace of economic growth in developing countries.

Following are the main steps which help to reduce poverty and increase the pace of economic growth in developing countries.

- In developing countries most of the people living in rural area. So government must increase the basic facilities in rural area which increase the living standard of the people.

- Provide more facilities of health and education in rural areas of the developing countries and provide more employment opportunities to people living in rural area.

- Provide equal opportunity to women in rural areas because most of the females in rural area are involved in agricultural activities such as poultry, dairy and stitching. As compare to this, women of urban area are doing jobs in schools, banks, hospitals and almost in all the sectors of society.

- Government should provide better opportunities to women so they can play their role in economic development of the country. 
- Promote gender equality in all the fields so that women play their active role in all the fields of life.

- Government must increase investment in human capital to provide basic facilities of life and to increase the living standard of people in the country.

- Take measure to increase exports which are helpful in balance of payments.

- To increase education and health facilities in the rural area which are helpful to increase literacy rate in the country?

- All these steps are helpful to increase economic growth in the developing countries. These steps are very important for the poverty reduction in the developing countries. 
Pakistan Journal of Humanities and Social Sciences, 6(4), 2018

\section{References}

Akoum, I. F. (2008).“Globalization, Growth, and Poverty: the missing link”.International Journal of Social Economics, 35,226-238.

Azam, M. \&Emirullah, C. (2014)."The Role of Governance in Economic Development”. International Journal of Social Economics,41, 1265-1278.

Boukhatem, J. (2016). Assessing the direct effect of financial development on poverty reduction in a panel of low-and middle-income countries. Research in International Business and Finance, 37, 214-230.

Crenshaw, E. M., Ameem, Z. A. \& Christenson, M. (1997). "Population Dynamic and Economic Development: age-specific population growth rates and economic growth in developing countries". American Sociological Review, 62(6), 974-984.

Dao, M. Q. (2012). "Population and Economic Growth in Developing Countries".International Journal of Academic Research in Business and Social Science, 2(1).

Donou-Adonsou, F., \& Sylwester, K. (2016). Financial development and poverty reduction in developing countries: New evidence from banks and microfinance institutions. Review of Development Finance, 6(1), 82-90.

Ferreira, F. H. G., Leite, P. G. \&Ravallion, M. (2010).“Poverty Reduction without Economic Growth?"Journal of Development Economics,93, 20-36.

Fosu, A. K. (2016). "Growth, Inequality and Poverty Reduction in Developing Countries: Recent Global Evidence". Research in Economics.

GOH, C. C., LUO, X. \&ZHU, N. (2009). "Income Growth, Inequality and Poverty Reduction: A case study of eight provinces in China". China Economic Review,20, 485-496.

Kalirajan, K. \& Singh, K. (2009)."The Pace of Poverty Reduction Across the Globe: an exploratoryanalysis".International Journal of Social Economics, 36, 692-705.

Kibirige, J. S. (1997). "Population Growth, Poverty and Health".Social Science Medium, 45(2), 247-259.

Kraay, A. \&Raddatz, C. (2007).“Poverty Traps, Aid and Growth”.Journal of Development Economics, 82, 315-347.

Krishan, T. N. (1992). "Population, Poverty and Employment in India".Economic and Political Weekly, 27(46), 2479-2489 + 2492-2497.

Mehanna, R. A. (2004). "Poverty and Economic Development: not as direct as it may seem".Journal of Socio-Economics,33, 217-22.

Montalvo, J. G. \&Ravallion, M. (2010). "The Pattern of Growth and Poverty Reduction in China".Journal of Comparative Economics,38, 2-16.

Mutula, S. M. (2008)."Digital Divide and Economic Development: case study of sub-Saharan Africa". The Electronic Library, 26, 468-489.

Nissim, B. D. (2007)."Economic Growth and its Effect on Income Distribution" Journal of EconomicStudies, 34, 42-58.

Northrop, E. M. (1988). "Economic Growth and Poverty Reductions: Important Mitigating Factors". Eastern Economic Journal, 14(4), 349-356.

Ohiorhenuan, J. F. E. (2011). "The Future of Poverty and Development in Africa".Foresight, 13, 7-23.

Oliver, M. (2015).“Population Ageing and Economic Growth in Japan”.International Journal of Sociology and Social Policy, 35, 841-863.

Oskooee, M. B. \&Oyolola, M. (2009). "Poverty Reduction and Aid: cross-country evidence".International Journal of Sociology and Social Policy, 29, 264-273. 
Prasad, N. (2008)."Growth and Social Development in the Pacific Island Countries”.InternationalJournalof Social Economics, 35, 930-950.

Qureshi, M. A. (2009). "Human Development, Public Expenditure and Economic Growth:asystem dynamics approach".International Journal of Social Economics, 36, 93-104.

Saab, G. (2007). "A Study of Economic Growth and Development in the Economic and Social Commissionfor Western Asia (ESCWA) Countries".Competitiveness Review: An International Business Journal,17, 153-161.

Salvatore, D. (2007). "Growth, International Inequalities and Poverty in a Globalizing World".Journal of Policy Modeling,29, 635-641.

Sasmal, R. \&Sasmal, J. (2016)"Public Expenditure, Economic Growth and Poverty Alleviation".International Journal of Social Economics, 43, 604-618.

Seven, U., \& Coskun, Y. (2016). Does financial development reduce income inequality and poverty? Evidence from emerging countries. Emerging Markets Review, 26, 34-63.

Sinding, S. W. (2009). "Population, Poverty and Economic Development".Philosophical Transactions: Biological Sciences, 364(532), 3023-3030.

Siwar, C. \&Kasim, M. Y. (1997)."Urban Development and Urban Poverty in Malaysia”.International Journal of Social Economics, 24, 1524-1535.

Spencer, J. \& Myer, R. (2007).“A Population and Economic Overview of Cambria County, Pennsylvaniafollowing the 1977 Johnstown Flood".Disaster Prevention and Management: an international journal, 16, 259-264.

Uddin, G. S., Shahbaz, M., Arouri, M., \& Teulon, F. (2014). Financial development and poverty reduction nexus: A cointegration and causality analysis in Bangladesh. Economic Modelling, 36, 405-412. 